\title{
ВАРІАНТИ ПЕРЕБІГУ ХЛАМІДІЙНОЇ ІНФЕКЦІї У ПРАКТИЦІ ЛІКАРІВ РІЗНИХ СПЕЦІАЛЬНОСТЕЙ
}

\author{
๑С. І. Климнюк, В. П. Борак, Л. Б. Романюк, Н. Я. Кравець, В. Т. Борак, \\ Н. І. Ткачук, Г. Р. Малярчук, Н. М. Олійник, І. М. Галабіцька
}

ДВНЗ «Тернопільський державний медичний університет імені І. Я. Горбачевського МОЗ України»

РЕзЮМЕ. Актуальність проблеми хламідіозів на сьогодні надзвичайно велика - у зв'язку зі значним поширенням хвороби та різноманітністю клінічних проявів. Хламідії спричиняють полісистемні та поліорганні ураження, що знаходить відображення у відповідних діагнозах. За клініко-епідеміологічними характеристиками проблема хламідіозів знаходиться у зоні професійних інтересів інфекціоністів, урологів, окулістів, акушерів-гінекологів, ревматологів. Необізнаність про них (особливо щодо атипових форм) не тільки лікарів первинної ланки обслуговування, а й фахівців інших спеціальностей, призводить до несвоєчасної діагностики та верифікації діагнозу і, відповідно, відсутності адекватного лікування.

Метою нашого дослідження було дослідити частоту виникнення атипових форм хламідіозу у пацієнтів, що звертаються до лікарів різних спеціальностей.

Матеріал і методи. Нами обстежено 17 пацієнтів із синдромом Рейтера хламідійного ґенезу, чоловіків було 15, жінок - 2, що збігається з даними літератури. Основним методом верифікації діагнозу був імуноферментний аналіз (IФА) для виявлення специфічних IgM i G.

Результати. Хворі, що були включені у дослідження, зі скаргами зверталися до різних спеціалістів (ревматолога, інфекціоніста, уролога, гінеколога, офтальмолога і сімейного лікаря). Найчастіше було діагностовано уретрит, дизуричні розлади, реактивний артрит, кератокон'юнктивіт, увеїт, кератит. Проте синдром Рейтера при першій консультації було встановлено лише 5 пацієнтам (29,41 \%), що свідчить про низьку настороженість щодо цього захворювання і вибір помилкової тактики лікування, яка не враховує етіологічну першопричину виникнення цього синдрому. Синдром Рейтера при другому зверненні було виявлено у 7 хворих $(41,78$ \%), а решті хворих (29,41 \%) діагноз було встановлено лише після консультації із суміжними спеціалістами.

Висновки. Отже, сидром Рейтера на сьогоднішній день $є$ поширеним захворюванням, що трапляється у практиці різних спеціалістів. Цей синдром потребує подальшого вивчення для полегшення верифікації діагнозу і вибору правильної тактики лікування, що враховує етіологічну причину розвитку даного захворювання та чутливість збудника до сучасних антибактеріальних засобів, що і буде метою наших подальших досліджень.

КлючОВІ СлОВА: хламідійна інфекція; синдром Рейтера; етіологія; діагностика; лікування.

«Проблема інфекцій завжди привертала до себе увагу фахівців усіх медичних спечіальностей...»

І. В. Давидовський

Вступ. Актуальність проблеми хламідіозів на сьогодні надзвичайно велика -у зв'язку зі значним поширенням хвороби та різноманітністю клінічних проявів. Хламідії спричиняють полісистемні та поліорганні ураження, що знаходить відображення у відповідних діагнозах. За своїми клінікоепідеміологічними характеристиками проблема хламідіозів знаходиться у зоні професійних інтересів інфекціоністів, урологів, окулістів, акушерівгінекологів, ревматологів. Необізнаність щодо хламідійної інфекції (особливо щодо ії атипових форм) не тільки лікарів первинної ланки обслуго- вування, а й фахівців інших спеціальностей, призводить до несвоєчасної діагностики та верифікації діагнозу і, відповідно, до відсутності адекватного лікування $[2,5]$. На сьогоднішній день відомо понад 40 хвороб і синдромів, спричинених хламідіями: трахома, респіраторні хвороби - фарингіт, трахеобронхіт, певмонія; гастроінтестинальні хвороби, поліартрит, гепатит, сечостатевий і аноректальний хламідіоз - більше 10 нозологій, нейрохламідіоз, міокардити, ендокардити, хвороби новонароджених, орнітоз, феліноз, хвороба Рейтера, вузлова еритема тощо (табл. 1) [3, 4].

Таблиця 1. Етіологічна характеристика хламідіозу

\begin{tabular}{|c|c|c|c|}
\hline Види & Біовар & Серовар & Ураження, що виникають у людини \\
\hline C. trachomatis & $\begin{array}{l}\text { Trachoma } \\
\text { LGV }\end{array}$ & $\begin{array}{l}\text { A, B, Ba, C } \\
D-K \\
L 1, L 2, L 2 a, L 3\end{array}$ & $\begin{array}{l}\text { Трахома, кон'юнктивіт з включеннями } \\
\text { Урогенітальний хламідіоз, кон'юнктивіт, } \\
\text { пневмонія новонароджених } \\
\text { Венерична лімфоргранульома }\end{array}$ \\
\hline C. pneumonia & TWAR & & Пневмонії, бронхіти \\
\hline C. psittaci & & Більше 10 сероварів & Орнітоз \\
\hline
\end{tabular}


Огляди літератури, оригінальні дослідження, погляд на проблему, ювілеї

Хламідії- це особливі мікроорганізми, характерною особливістю яких $\epsilon$ внутрішньоклітинний паразитизм, зумовлений відсутністю у них ферментних систем енергетичного обміну, через що вони $\epsilon$ «облігатними енергетичними паразитами» клітини. Морфологію хламідій вивчають, досліджуючи їхні специфічні структури - внутрішньоклітинні включення. В циклі розвитку хламідій розрізняють кілька стадій: елементарне, ретикулярне та проміжне тільця [1].

Елементарні тільця - дрібні (0,15-0,2 мкм) утворення, що здатні виживати поза клітиною, вони мають інфекційні властивості, здатні проникати в клітину, де вони переходять у ретикулярні тільця. При цьому вони збільшуються в розмірах до 1 мкм, активують обмінні процеси і починається бінарний поділ, у результаті якого утворюються внутрішньоклітинні включення. Включення мають вигляд вакуолей, розміщених у цитоплазмі або поблизу ядра клітини. Їх виявляють при диференційному забарвленні клітин.

Орнітоз - гостра інфекційна хвороба з групи зоонозів, яку спричинює Chlamidia psitaci з роду хламідій. Характеризується інтоксикацією організму, ураженням легень, нервової системи, гепатолієнальним синдромом. Орнітоз реєструють повсюдно. На сьогодні тільки у США щорічно виявляють до 200 випадків орнітозу. Але вважають, що реальні цифри значно більші, оскільки це захворювання складно діагностувати через нетиповий клінічний перебіг, а також унаслідок широкого застосування в якості емпіричної терапії макролідів, до яких збудник чутливий. Частіше хворіють особи середнього і старшого віку. В останні роки занепокоєння викликає збільшення випадків захворювання в розвинених країнах, що пов'язано із великим імпортом екзотичних птахів [1].

Джерелом збудника в природних умовах $\epsilon$ близько 170 видів птахів, у яких ця інфекція, як правило, перебігає латентно, але в несприятливих умовах може розвинутися захворювання. У містах основним резервуаром $\epsilon$ кімнатні птахи і голуби, у яких збудник виділяється в довкілля з фекаліями і слизом носових ходів. Передається інфекція аерогенним шляхом. Трапляються випадки лабораторного інфікування. Сприйнятливість до орнітозу висока, частіше хворіють працівники птахофабрик, мисливці, любителі голубів та кімнатних птахів [2].

Феліноз (хвороба від котячих подряпин) гостра бактерійна хвороба, що характеризується інтоксикацією, гарячкою, регіональним лімфаденітом, іноді первинним афектом та екзантемою. Вперше хворобу описали 1950 p. R. Debre i, незалежно від нього, P. Mollaret, хоча ще 1932 р. R. Debre довів інфекційність хвороби і назвав ії доброякісним вірусним лімфаденітом.

Хламідійна інфекція органа зору, що часто поєднується з урогенітальною та суглобовою патологією (синдром Рейтера або уретроокулосиновіальний синдром) - гнійний кон'юнктивіт, уретрит, артрит [1].

Урогенітальнийхламідіоз-одна знайпоширеніших інфекцій, що передається статевим шляхом i $€$ серйозною медичною і соціальною проблемою охорони здоров'я багатьох країн. В акушерській практиці ця інфекція $\epsilon$ однією з основних причин патології плода і новонародженого. Інфікування плода Chlamidia trachomatis може призвести до його антенатальної загибелі, гіпоксії, передчасних пологів, народження дитини з ураженням центральної нервової, серцево-судинної, дихальної систем, шлунково-кишкового тракту, очей, чи генералізованою формою інфекції. Своєчасно розпочате лікування хламідійної інфекції у вагітної запобігає розвитку ускладнень перебігу вагітності та ураженню плода. Однак, зважаючи на безсимптомний і малосимптомний перебіг, поліморфізм проявів за маніфестних форм хвороби, клінічна діагностика урогенітального хламідіозу значно ускладнюється. Верифікацію діагнозу, як правило, проводять на підставі результатів спеціальних лабораторних досліджень.

Респіраторний хламідіоз, як правило, спричиняється Chlamidia pneumoniae і дуже рідко Chlamidia trachomatis (табл. 2). Частіше хворіють немовлята. Хвороба може пребігати у формі бронхіту або превмонії.

Таблиця 2. Патогенетичні особливості роду Chlamidia

\begin{tabular}{|l|l|l|}
\hline \multicolumn{1}{|c|}{ Види } & \multicolumn{1}{|c|}{ Характер ураження } & \multicolumn{1}{|c|}{$\begin{array}{l}\text { Природний хазяїн, } \\
\text { механізм передачі }\end{array}$} \\
\hline C. trachomatis & $\begin{array}{l}\text { Трахома і паратрахома. } \\
\text { Урогенітальний хламідіоз і пневмонія } \\
\text { новонароджених } \\
\text { Венерична лімфогранульома }\end{array}$ & $\begin{array}{l}\text { Люди } \\
\text { Статевий контакт, } \\
\text { пренатальна передача }\end{array}$ \\
\hline C. psitaci & Орнітози & $\begin{array}{l}\text { Птахи } \\
\text { Інгаляція сухих виділень птахів }\end{array}$ \\
\hline C. pneumoniae & $\begin{array}{l}\text { Пневмонія, ГР3, атеросклероз, саркоїдоз, } \\
\text { бронхіальна астма }\end{array}$ & $\begin{array}{l}\text { Люди } \\
\text { Повітряно-крапельний шлях }\end{array}$ \\
\hline
\end{tabular}


Огляди літератури, оригінальні дослідження, погляд на проблему, ювілеї

Діагностика хламідіозів ґрунтується на епідеміологічних даних (робота з хворими тваринами, контакт з птахами, вживання контамінованих продуктів) і таких характерних ознаках як гарячка, біль у суглобах, ураження склер і кон'юнктивіт, неврологічні прояви, біль у суглобах. Для діагностики хламідіозів використовують мікроскопічний метод - виявлення тілець-включень у клітинах; серологічний метод - виявлення антитіл та їх динаміка в Р3К (реакції зв'язування комплементу) або антитіл класів IgG та М методом імуноферментного аналізу (ІФА); виявлення антигенів хламідій у клітинах (імунолюмінесцентний метод) або в іншому матеріалі (ІФА); виявлення ДНК хламідій за допомогою полімеразної ланцюгової реакції (ПЛР) [2].

Препаратами вибору для лікування хламідійної інфекції $є$ антибіотики, що проникають в інфіковані клітини, - тетрацикліни, а також макроліди [5].

Таким чином, проблема хламідіозу на сьогоднішній день залишається надзвичайно актуальною, багато питань щодо етіології, патогенезу, клінічної симптоматики та лікування даного захворювання $\epsilon$ недостатньо вивченими і потребують подальших досліджень.

Метою нашого дослідження було вивчити частоту виникнення атипових форм хламідіозу у пацієнтів, що звертаються до лікарів різних спеціальностей.

Матеріал і методи дослідження. Нами обстежено 17 пацієнтів із синдромом Рейтера хла- мідійного генезу. Основним методом верифікації діагнозу був імуноферментний аналіз (IФА) для виявлення специфічних IgM i G. Чоловіків було 15, жінок - 2, що збігається з даними літератури.

Результати й обговорення. Хворі, включені у дослідження, зі скаргами зверталися до різних спеціалістів (ревматолога, інфекціоніста, уролога, гінеколога, офтальмолога і сімейного лікаря). Найчастіше було діагностовано уретрит, дизуричнірозлади, реативний артрит, кератокон'юнктивіт, увеїт, кератит. Проте синдром Рейтера при першій консультації було діагностовано лише 5 пацієнтам (29,41 \%), що свідчить про низьку настороженість лікарів різних спеціальностей щодо цього захворювання і вибір помилкової тактики лікування, що не враховує етіологічної першопричини виникнення даного синдрому. Синдром Рейтера при другому зверненні було виявлено у 7 хворих (41,78 \%), а решті хворих $(29,41 \%)$ цей діагноз було встановлено лише після консультації із суміжними спеціалістами.

Висновки. Синдром Рейтера на сьогоднішній день $є$ поширеним захворюванням, що трапляється у практиці різних спеціалістів. Цей синдром потребує подальшого вивчення для полегшення верифікації діагнозу і вибору правильної тактики лікування, яка 6 враховувала етіологічну причину розвитку даного захворювання та чутливість збудника до сучасних антибактеріальних засобів, що і буде метою наших подальших досліджень.

\section{ЛІТЕРАТУРА}

1. Федоренко С. М. Клінічні форми хламідіозів. Хвороба Рейтера / С. М. Федоренко, В. М. Тітов, О. С. Луцук, С. П. Сельвестр // Інфекційні хвороби у клінічній та епідеміологічній практиці. - 2009. - С. 303-305.

2. Тітов В. М. До проблеми хламідіозів / В. М. Тітов, С. М. Федоренко, О. С. Луцук [та ін.] // Інфекційні хвороби: діагностика і проблеми в діагностиці та терапії. Вінниця, 2010. - С. 426-428.

3. Господарський І. Я. Етіотропне лікування пацієнтів зі синдромом Рейтера / І. Я. Господарський, Х. О. Гос-

подарська // Досягнення і проблеми клінічної інфектології. - Тернопіль, 2008. - С. 277-278.

4. Осипов П. Г. Современная антибиотикотерапия в лечении больных с урогенитальным хламидиозом препаратом ломефлоксацин / П. Г. Осипов // Научные ведомости. - 2014. - № 11. - С. 27-29.

5. Петрух Л. І. Хламідіоз. Флуренізид. Супозиторії антихламідійної дії / Л. І. Петрух, О.В.Павленко; автор передмови Л. І. Петрух. - Л. : Наукове товариство ім. Шевченка, 2015. - 348 с.

\section{REFERENCES}

1. Fedorenko, S.M., Titov, V.M., Lutsuk, O.S., \& Selvestr, S.P. (2009). Klinichni formy khlamidioziv. Khvoroba Reitera. Infektsiini khvoroby u klinichnii ta epidemiolohichnii praktytsi [Clinical forms of chlamydia. Reiters disease. Infectious diseases in clinical and epidemiological practice]. Lviv [in Ukrainian].

2. Titov, V.M., Fedorenko, S.M., Lutsuk, O.S., Nakonechnyi, I.A., Hychka, M.M., Selvestr, S.P., \& Kukhar, M.H. (2010). Do problemy khlamidioziv. Infektsiini khvoroby: diahnostyka i problemy v diahnostytsi ta terapii [Infectious diseases: diag-

nostics and problems in diagnostics and therapy]. Vinnytsia [in Ukrainian].

3. Hospodarskyi, I.Ya., \& Hospodarska, Kh.O. (2008). Etiotropne likuvannia patsiientiv zi syndromom Reitera. Dosiahnennia i problemy klinichnoi infektolohii [Etiotropic treatment of patients with Reiters syndrome. Achievements and problems of clinical infectology]. Ternopil [in Ukrainian].

4. Osipov, P.G. (2014). Sovremennaya antibiotikoterapiya v lechenii bolnykh s urogenitalnym khlamidiozom pre- 
Огляди літератури, оригінальні дослідження, погляд на проблему, ювілеї

paratom lomefloksatsin [Modern antibiotic therapy in the treatment of patients with urogenital chlamydiosis with lomefloxacin]. Nauchnyye vedomosti - Scientific Statements, 11, 27-29 [in Russian].
5. Petrukh, L.I., \& Pavlenko, O.V. (2015). Khlamidioz. Flurenizyd. Supozytorii antykhlamidiinoi dii [Chlamydia flurenizide suppositories of antichlamidal action]. Lviv: Naukove tovarystvo im. Shevchenka [in Ukrainian].

\title{
ВАРИАНТЫ ТЕЧЕНИЯ ХЛАМИДИЙНОЙ ИНФЕКЦИИ В ПРАКТИКЕ ВРАЧЕЙ РАЗЛИЧНЫХ СПЕЦИАЛЬНОСТЕЙ
}

\author{
๑С. И. Климнюк, В. П. Борак, Л. Б. РоманюК, Н. Я. Кравец, В. Т. Борак, \\ Н. И. Ткачук, А. Р. Малярчук, Н. М. Олийник, И. М. Галабицькая \\ ГВУЗ «Тернопольский государственный медицинский университет имени И. Я. Горбачевского \\ МОЗ Украины»
}

РЕЗЮМЕ. Актуальность проблемы хламидиоза сегодня чрезвычайно велика - в связи с широким распространением болезни и разнообразием ее клинических проявлений. Хламидии вызывают полисистемные и полиорганные поражения, что находит отображение в соответствующих диагнозах. По своим клинико-эпидемиологическим характеристикам проблема хламидиоза находится в зоне профессиональных интересов инфекционистов, урологов, окулистов, акушеров-гинекологов, ревматологов. Неосведомленность о них (особенно в отношении атипичных форм) не только врачей первичного звена обслуживания, но и специалистов других специальностей, приводит к несвоевременной диагностике и верификации диагноза и, соответственно, отсутствию адекватного лечения.

Целью нашего исследования было определить частоту возникновения атипичных форм хламидиоза у пациентов, обращающихся к врачам различных специальностей.

Материал и методы. Нами обследовано 17 пациентов с синдромом Рейтера хламидийного генеза, мужчин было 15, женщин - 2, что совпадает с данными литературы. Основным методом верификации диагноза был иммуноферментный анализ (ИФА) для выявления специфических IgM и G.

Результаты. Больные, которые были включены в исследование, с жалобами обращались к разным специалистам (ревматологу, инфекционисту, урологу, гинекологу, офтальмологу и семейному врачу). Чаще всего были диагностированы уретрит, дизурические расстройства, реактивний артрит, кератоконъюнктивит, увеит, кератит. Однако синдром Рейтера при первой консультации был диагностирован лишь у 5 пациентов (29,41\%), что свидетельствует о низкой настороженности относительно этого заболевания и выборе ошибочной тактики лечения, которая не учитывает этиологической первопричины возникновения синдрома. Синдром Рейтера при втором обращении был обнаружен у 7 больных (41,78 \%), а у остальных больных $(29,41$ \%) диагноз был установлен только после консультации со смежными специалистами.

Выводы. Сидром Рейтера на сегодняшний день является распространенным заболеванием, встречается в практике различных специалистов. Этот синдром требует дальнейшего изучения для облегчения верификации диагноза и выбора правильной тактики лечения, учитывающей этиологическую причину развития данного заболевания и чувствительность возбудителя к современным антибактериальным средствам, что и будет целью наших дальнейших исследований.

КЛЮЧЕВЫЕ СЛОВА: хламидийная инфекция; синдром Рейтера; этиология; диагностика; лечение.

\section{THE VARIANTS OF CHLAMYDIA INFECTION IN THE PRACTICE OF DOCTORS OF DIFFERENT SPECIALTIES}

\section{@S. I. Klymniuk, V. P. Borak, L. B. Romanyuk, N. Ya. Kravets, V. T. Borak, N. I. Tkachuk, H. R. Malyarchuk, N. M. Oliynik, I. M. Halabitska \\ I. Horbachevsky Ternopil State Medical University}

SUMMARY. The urgency of the chlamydiaes problem is extremely high today due to the widespread of the disease and the clinical manifestations diversity. Chlamydia causes polysystem and multiorgan lesions, which are reflected in the corresponding diagnoses. According to its clinical and epidemiological characteristics, the problem of chlamydia is located in the zone of occupational interests of infectious disease, urologists, ophthalmologists, gynecologists, and rheumatologists, as well as the lack of knowledge about them (especially with regard to atypical forms), not only the primary care physicians, but also specialists of other specialties, leads until untimely diagnosis and verification of the diagnosis and the lack of adequate treatment. The problem of chlamydia today remains extremely relevant, many questions regarding the etiology, pathogenesis, clinical symptoms and treatment of this disease are underdeveloped and require further research. 
Огляди літератури, оригінальні дослідження, погляд на проблему, ювілеї

The aim of our study was to investigate the incidence of atypical forms of chlamydia in patients who seek medical doctors of various specialties.

Material and Methods. We examined 17 patients with Reuters Chlamydial Genesis syndrome. The main method for verifying the diagnosis was ELISA for the detection of specific $\lg M$ and $\lg$ G. Male were 15 , female -2 , which coincides with the literature.

Patients who were included in the study with complaints turned to various specialists (rheumatologist, infectious disease, urologist, gynecologist, ophthalmologist and family doctor). Often, urethritis, dysuric disorders, reagent arthritis, keratoconjunctivitis, uveitis, and keratitis were diagnosed. However, Reiter's syndrome at the first consultation was presented to only 5 patients $(29.41 \%)$, indicating low alertness for this disease and the choice of false treatment tactics that does not take into account the etiological root cause of this syndrome. Reiter's syndrome at the second treatment was detected in 7 patients (41.78 \%). The rest of the patients ( $29.41 \%)$ were exposed only after consulting with related specialists.

Conclusions. Reiter's syndrom today is a common disease that occurs in the practice of various specialists. This syndrome requires further study to facilitate verification of the diagnosis and the choice of the correct treatment tactics that takes into account the etiological cause of the development of this disease and the sensitivity of the pathogen to modern antibacterial agents, which will be the purpose of our further research.

KEY WORDS: Chlamydia infection; Reiter syndrome; etiology; diagnostics; treatment. 